\title{
Different particle sources in a bivalve species of a coastal lagoon: evidence from stable isotopes, fatty acids, and compound-specific stable isotopes
}

\author{
Mathieu-Resuge Margaux 1, 4, ${ }^{*}$, Schaal Gauthier ${ }^{1}$, Kraffe Edouard ${ }^{1}$, Corvaisier Rudolph ${ }^{1}$, \\ Lebeau Oanez ${ }^{2}$, Lluch-Cota Salvador E. ${ }^{3}$, Salgado García Rosa L. ${ }^{3}$, Kainz Martin J. ${ }^{4}$, \\ Le Grand Fabienne ${ }^{1}$
}

1 Univ Brest, CNRS, IRD, Ifremer, LEMAR, IUEMPlouzané,France

2 Univ Brest, CNRS, UMS3113, IUEMPlouzané,France

${ }^{3}$ Centro de Investigaciones Biológicas del Noroeste (CIBNOR)La Paz,Mexico

${ }^{4}$ WasserCluster Lunz-Inter-University Centre for Aquatic Ecosystem ResearchLunz am See,Austria

*Corresponding author : Margaux Mathieu-Resuge, email address : m.mathieuresuge@gmail.com

\begin{abstract}
:
The trophic fate of various food sources is of central interest for ecologists, yet not well understood in coastal lagoon food webs. In this field study, fatty acids (FA), stable isotopes (SI), and compound-specific isotopic analysis (CSIA) on FA were used to investigate how diets from oceanic and local sources are retained in a bivalve species (Spondylus crassisquama; Lamarck 1819) along a transect in the Ojo de Liebre lagoon (BCS, Mexico). Results from SI and FA indicated the contribution of oceanic diatoms at the entrance of the lagoon, through $15 \mathrm{~N}$ enrichment, and higher proportions of $16: 1 n-7$ and $20: 5 n-3$ in digestive glands. In the inner bay, higher abundance of 18-carbon FA (18:1n-9, 18:3n-3, 18:4n-3) suggested a higher contribution of microheterotrophs, including (dino)flagellates and ciliates, to the diet of this bivalve derived from local production. Significant spatial differences for the $\delta 13 \mathrm{C}$ of FA highlighted changes in the origin of food sources. Indeed, a $13 \mathrm{C}$ depletion was observed in the $\delta 13 \mathrm{C}$ of heterotrophic flagellates biomarkers in individuals from the innermost station, revealing that their origin in the diet of bivalves differs within the lagoon, highlighting the importance of local processes (sediment resuspension, remineralization) in the trophic functioning of the lagoon. The $\delta 13 \mathrm{C}$ values of FA considered as diatoms biomarkers (16:1n-7 and 20:5n-3) were consistent, which suggests that diatoms assimilated have very similar origins throughout the lagoon. The complementary of the tracers used here allowed for a better understanding of the trophic functioning of this coastal lagoon submitted to oceanic influences.
\end{abstract}




\section{Introduction}

Coastal lagoons are complex and productive ecosystems, and their primary production is supported by a highly diverse origin of nutrients (Nixon 1982). At the interface between land and ocean, lagoons are characterized by shallow water and a large diversity of potential food sources, including continental inputs, salt marsh, seagrass, macroalgae, and phytoplankton, and resulting in marked spatial patterns in food web interactions (Carlier et al. 2008; Clavier et al. 2014). In coastal lagoons, benthic assemblages are largely dominated by suspensionfeeding bivalves (Bachelet et al. 2000). Because these organisms are sedentary primary consumers, they are good indicators of processes occurring at the base of the food web (Marchais et al. 2013). Therefore, studying the nature and the origin of food sources involved in their diet provides a spatially and temporally integrated overview of organic matter transfer between benthic and pelagic systems, and across ecosystem boundaries (i.e., between lagoons and the nearby coastal ocean).

The trophic ecology of suspension-feeding invertebrates inhabiting coastal environments has been extensively investigated over the last 20 years using indirect biomarker-based approaches. Among the most common, the analysis of bulk carbon and nitrogen stable isotopes (SI) has provided valuable insights into the origin and nature of bivalve food sources (Riera 2007; Marchais et al. 2013). Because primary producers typically display contrasted SI composition according to their benthic vs pelagic (France 1995) or freshwater vs marine (Riera and Richard 1996) origin, and because the SI composition of consumers are indicative of their source, this approach is currently widely used to address questions in trophic ecology (Fry 1988; Layman et al. 2012). However, to be efficient, this method requires primary producers displaying contrasted SI composition. Although different species of planktonic microalgae can vary in their SI values (Falkowski 1991; Vuorio et al. 2006), it is 
generally difficult to differentiate between potential diet sources that share the same habitat (Kharlamenko et al. 2001). Therefore, it remains a challenge for bulk SI ecology to assess the dietary contribution of different primary producers to consumers.

The analysis of fatty acids (FA) is a powerful and complementary approach, which is based on the assumption that most animals have limited ability to biosynthesize polyunsaturated FA (PUFA) or FA of bacterial origin de novo (Budge et al. 2006), and thus the FA composition of a consumer resembles that of its food source (Dalsgaard et al. 2003). Among the different FA synthesized by primary producers, some of them are considered as trophic biomarkers because they characterize specific food sources; for example, palmitoleic acid (16:1n-7) and eicosapentaenoic acid (20:5n-3) are used as biomarkers of diatoms, and stearidonic acid (18:4n-3) and docosahexaenoic acid (22:6n-3) are abundant in (dino)flagellates (Parrish et al. 2000; Kharlamenko et al. 2001; Alfaro et al. 2006). Therefore, it is possible to assess the contribution of specific taxonomic groups (e.g. diatoms, dinoflagellates, marine plants) in the diet of primary consumers (Kelly and Scheibling 2012); by paying attention when analyzing bivalve tissues presenting different turnover rates resulting in diverse integrating dietary information over time (e.g. the digestive gland (DG), has faster turnover rates than muscle tissues) (Lorrain et al. 2002; Dalsgaard et al. 2003; Nerot et al. 2015). Because SI can be useful in assessing food sources, in particular when using stable $\mathrm{C}$ and $\mathrm{N}$ isotopes in combination (Lorrain et al. 2002; Schaal et al. 2016) and FA can differentiate between algal, bacterial or even terrestrial sources (Kainz et al. 2002), these two approaches have been successfully used in combination to unravel trophodynamic trajectories in a variety of coastal environments (Alfaro et al. 2006; Jaschinski et al. 2008; Allan et al. 2010). The combined use of SI and FA is based on the assumption that specific SI values or FA molecules are attributed to distinct sources, which is unlikely in complex ecosystems (Kharlamenko et 

al. 2001). For instance, it would be impossible to characterize the precise origin (i.e. oceanic or coastal) of the diet of a suspension feeder assimilating planktonic dinoflagellates and benthic diatoms using only bulk SI and FA approaches.

Compound-specific isotope analysis (CSIA) represents an ecologically complementary approach, through which the identification of the SI composition of source-specific compounds can characterise their origin. For example, CSIA has been successfully used in trophic ecology to highlight the contribution of ice algae to the diet of bivalves (Gaillard et al. 2017), or dietary shifts in benthic invertebrates at the vicinity of finfish farming (Colombo et al. 2016).

Lagoon, such as the Ojo de Liebre lagoon (Baja California Sur, Mexico), are of particular interest for trophic ecology as they rely on a wide diversity of both local sources (autochthonous) such as local phytoplankton or resuspended benthic sources, including eelgrass detritus (Zostera marina; Linnaeus, 1753), and allochthonous sources, such as oceanic phytoplankton supplied to the lagoon by tide current, especially during important oceanic events occurring from April to June in this region (Du et al. 2015)..

In this context, the aim of this study was to apply three trophic biomarker-based approaches to examine spatial patterns of organic matter sources and their biochemical composition assimilated by S. crassisquama. It was hypothesized that lower oceanic phytoplankton availability in the inner part of the lagoon, which is less connected to the ocean, would result in higher reliance on local food sources. Stable isotope, FA, and CSIA values in consumers located close the ocean were thus expected to resembled those of the ocean, testing the effect of spatial diet proximity to the ocean and how far its impact is perceived inside the lagoon; by contrast,consumers furthest away from the ocean were isotopically and in their 
116 FA composition expected to be closer to the autochthonous diet sources highlighting the

117 effect of local diet incorporation.

118 

Sampling

121 The Ojo de Liebre lagoon is a $446 \mathrm{~km}^{2}$ lagoon situated on the Pacific coast of Baja California

122 hosting one of the most important bivalve fishery (in particular Spondylus crassiquama;

123 Lamarck 1819) of western Mexico, was sampled in June 2017 at three stations along a

124 transect (Fig. 1); Station 1: located $3.5 \mathrm{~km}$ outside the bay; Station 2: at $6.1 \mathrm{~km}$ from the

125 mouth, inside the lagoon; and Station 3: $15.5 \mathrm{~km}$ inside the lagoon. Sampling depths ranged

126 from 7 to $10 \mathrm{~m}$. Stations 1 and 3 corresponded to the most outer and inner sites,

127 respectively, where the target species, Spondylus crassisquama, could be found. At each

128 station, 10 individuals of $S$. crassisquama of similar size ( $12 \mathrm{~cm}$ of length), and potential

129 food sources (particulate organic matter; POM, and, sediment-water interface organic

130 matter; SOM) were collected by scuba divers. The Zostera marina fragments, at two

131 different degradation stages (later called fresh and detrital), were also collected from the

132 shore at the eastern part of the sampling area. Bivalves were placed in cooler boxes with

133 water from sampling sites at ambient temperature, while collected surface water and

134 sediment cores and eelgrass detritus were protected from light using black plastic bags until 135 transportation (within 3 hours) to the lab facilities at the Northwestern Center for Biological 136 Research (CIBNOR, Guerrero Negro, BCS). Once in the laboratory, bivalve DG and adductor 137 muscles were dissected, packed and stored in liquid nitrogen.

138 Food sources (POM, SOM, and eelgrass fragments) were prepared for analysis by the 139 following methods; a) sediment-water interface were soaked in filtered sea water (GF/F 0.7

$140 \mu \mathrm{m})$, and allowed to settle. The supernatant containing fine organic particles (SOM),

141 potentially affected by resuspension events and therefore available to benthic suspension- 
feeders, was filtered on pre-combusted $\left(6 \mathrm{~h}, 450^{\circ} \mathrm{C}\right) \mathrm{GF} / \mathrm{F}$ filters. Four subsamples of SOM

143 (two for SI, and two for FA analyses) were prepared for each sampling station, packed and

144 frozen in liquid nitrogen; b) particles from surface water were filtered on pre-combusted (6

$145 \mathrm{~h}, 450^{\circ} \mathrm{C}$ ) GF/F filters until clogging. Immediately after filtration, filters subsamples of POM (

$146=2$ for $\mathrm{SI}$, and $\mathrm{n}=2$ for FA analyses) were packed and frozen in liquid nitrogen immediately

147 after filtration, and; c) large epiphytes were first removed from eelgrass fragments, which

148 were then packed and stored in liquid nitrogen. Once at the main laboratory (CIBNOR, La

149 Paz), all samples were stored at $-80^{\circ} \mathrm{C}$ until further analysis.

151 Muscles and eelgrass samples were freeze-dried (24 h) and homogenized using a ball mill.

152 Because bivalve muscles are generally poor in lipids, lipids were not removed from muscle

153 tissues prior to SI analysis (Lorrain et al. 2002). Indeed, the measured C:N ratios did not

154 exceed 3.5, rendering lipid removal unnecessary for SI analysis (Post et al. 2007). Muscle

155 tissues ( $25 \mathrm{mg}$ dry weight) and particles of SOM and POM (scraped off from the freeze-

156 dried filters; 1.5 mg dry weight) were packed in tin capsules ( $8 \times 5 \mathrm{~mm})$ for subsequent bulk

157 SI analysis.

158 All samples were analyzed by continuous flow on a Flash EA 2000 IRMS elemental analyzer

159 coupled to a isotope ratio mass spectrometer (IRMS; Thermo Fisher Scientific Delta V Plus).

160 Isotopic calibration was done using international standards (IAEA-600 Caffeine, IAEA-CH-6

161 Sucrose and IAEA-N-2 Ammonium Sulphate). The standard deviation calculated with the

162 acetanilide working standard (Thermo Scientific), repeatedly measured after 7 samples, was

$163 \pm 0.1 \%$ \% $(n=19)$ for both $\delta^{13} \mathrm{C}$ and $\delta^{15} \mathrm{~N}$. Results were expressed in delta $(\delta)$ units with

164 respect to international standards (Vienna Pee Dee Belemnite for $\delta^{13} \mathrm{C}$ and atmospheric 
165

nitrogen for $\left.\delta^{15} \mathrm{~N}\right)$, following the equation: $\delta^{13} \mathrm{C}$ or $\delta^{15} \mathrm{~N}=\left[\left(\mathrm{R}_{\text {sample }} / \mathrm{R}_{\text {standard }}\right)-1\right] \times 10^{3}$

166

\section{Separation of neutral lipids}

175 DG lipids were separated into neutral and polar lipids (the latter was not analyzed in the present study) following the method described elsewhere (Le Grand et al. 2014). In brief, an aliquot (1/6) of the total lipid extract was evaporated under nitrogen, recovered with 3 washes using chloroform/methanol $(0.5 \mathrm{~mL} ; 98: 2 ; \mathrm{v} / \mathrm{v})$ and spotted at the top of a silica gel

179 column (40 mm x $4 \mathrm{~mm}$, silica gel 60A 63-200 $\mu$ m rehydrated with $6 \% \mathrm{H}_{2} \mathrm{O} ; 70-230$ mesh).

180 Neutral lipids (NL) were eluted using chloroform/methanol (10 mL; 98:2; v/v) and collected

181 in glass vials containing an internal standard (2.3 $\mu \mathrm{g}$ of tricosanoic acid; C23:0). Lipid

182 fractions were then stored at $-20^{\circ} \mathrm{C}$ until further analyses.

Fatty acid analysis by gas chromatography

184 The NL fraction of DG as well as aliquots of POM, SOM and eelgrass total lipid extracts were evaporated to dryness under nitrogen. Fatty acids methyl esters (FAME) were obtained by 
187

188

189

190

191

192

193

194

195

196

197

198

199

200

201

202

203

204

205

206

207

208

209

transesterification was performed by the addition of $0.8 \mathrm{~mL}$ of a $\mathrm{H}_{2} \mathrm{SO}_{4} /$ methanol mixture

$(3.4 \% ; \mathrm{v} / \mathrm{v})$ to the dried extracts containing $\mathrm{NL}$ and heated at $100^{\circ} \mathrm{C}$ for $10 \mathrm{~min}$. After cooling, hexane $(0.8 \mathrm{~mL})$ and distilled water saturated in hexane $(1.5 \mathrm{~mL})$ were added. Vials were then homogenized and centrifuged (at $738 \mathrm{~g}$ for $1 \mathrm{~min}$ at $20^{\circ} \mathrm{C}$ ). Only the organic phasecontaining FAME was kept and washed two more times with distilled water saturated in hexane $(1.5 \mathrm{~mL})$. At each step, the aqueous phase was discarded.

Analyses of FAME were conducted on a Varian CP8400 gas chromatograph (GC), by simultaneous separation on two columns with two different phase polarities: one polar (ZBWAX: $30 \mathrm{~m} \times 0.25 \mathrm{~mm}$ ID $\times 0.2 \mu \mathrm{m}$, Phenomenex) and another apolar column (ZB5HT: 30 $\mathrm{m} \times 0.25 \mathrm{~mm}$ ID $\times 0.2 \mu \mathrm{m}$, Phenomenex). The GC runs followed these temperature programs: the $\mathrm{GC}$ oven temperature was raised to $150^{\circ} \mathrm{C}$ at $50^{\circ} \mathrm{C} \mathrm{min}{ }^{-1}$, then to $170^{\circ} \mathrm{C}$ at $3.5^{\circ} \mathrm{C} \mathrm{min}^{-1}$, to $185^{\circ} \mathrm{C}$ at $1.5^{\circ} \mathrm{C} \mathrm{min}^{-1}$, to $225^{\circ} \mathrm{C}$ at $2.4^{\circ} \mathrm{C} \mathrm{min}^{-1}$, and finally to $250^{\circ} \mathrm{C}$ at $5.5^{\circ} \mathrm{C} \mathrm{min}-1$ and maintained for $15 \mathrm{~min}$ ) and equipped of two splitless injectors regulated at $220^{\circ} \mathrm{C}$, and two flame-ionization detectors $\left(280^{\circ} \mathrm{C}\right)$, using hydrogen as vector gas. Identification of FAME was realized by comparison of their retention times with those of commercial standards from Sigma (Supelco 37 Component FAME Mix, the PUFA No.1 and No.3, and the Bacterial Acid Methyl Ester Mix) and an in-house standard mix from marine bivalves and microalgae. The FA content (\%) was expressed as the mass percentage of the total FA content. Compound-specific isotopic analysis on fatty acids Five bivalve samples previously analyzed for FA composition were randomly selected for compound-specific isotopic analysis. The utilization of GC (Thermo Fisher Scientific GC ISOLINK TRACE ULTRA) allowed the separation of FAME using the same apolar phase (Agilent DB5) and the same analytical program as for GC-FID analysis (see above). Each of the FA was 
210

converted into $\mathrm{CO}_{2}$ by combustion in the ISOLINK furnace and transferred to the CONFLO IV

211 interface and then introduced to the IRMS (Delta V Plus; Thermo Fisher Scientific). As above,

212 FAME were identified by comparison of their retention time with those of commercial

213 standards and in-house standard mixtures as described above. 18:1n-9 and 18:3n-3 did

214 coelute on the apolar column used in GC-C-IRMS analysis, and were therefore analyzed

215 simultaneously. Fatty acids kept for $\delta^{13} \mathrm{C}$ analyses were selected based on their abundance

216 and detection in CSIA (i.e., with amplitudes $>800 \mathrm{mV}$ ).

217 Calibration of $\delta^{13} \mathrm{C}$ values

218 The $\delta^{13} \mathrm{C}$ values were calibrated using the F8-3 standard mixture of eight acid ethyl and 219 methyl esters $\left(14: 0,16: 0,18: 0\right.$, and $20: 0$, with $\delta^{13} C$ values ranging from $-26.98 \pm 0.02 \%$ o to $22030.38 \pm 0.02 \%$ o) supplied by Indiana University Stable Isotope Reference Materials, inserted 221 before and after every 3 analytical replicates of each sample.

222 Correction of the $\delta^{13} \mathrm{C}$ contribution of the carbon added by trans-esterification

223 Because of the addition of a methyl group derived from the methanol used in the

224 transesterification reaction, $\delta^{13} \mathrm{C}$ of FAME analyzed here differed from the original $\delta^{13} \mathrm{C}$ of $\mathrm{FA}$

225 present in source material. To correct the contribution of the carbon from this additional

226 methyl group, several free FA (14:0, 16:0, 16:1n-7, 17:0, 18:0, 18:1n-9, 18:2n-6, 18:3n-3,

227 18:3n-6, 20:0, 20:4n-6, 20:5n-3, 22:0, 23:0, and 24:0; Sigma), were trans-esterified with the

228 same methanol as the one used for samples. Prior to trans-esterification, the $\delta^{13} \mathrm{C}$ values of

229 each of those free FA were determined by using continuous flow on a Flash EA2000

230 elemental analyzer coupled to a Delta V Plus mass spectrometer (Thermo Fisher scientific).

231 After trans-esterification of free $\mathrm{FA}$, the $\delta^{13} \mathrm{C}$ values of the resulting FAME were measured

232 using the GC-C-IRMS system. Then, an average correction was calculated using the following 
233

equation: $\delta^{13} C$ Methanol $=-n * \delta^{13} C_{F A}+(n+1) * \delta^{13} C_{F A M E}$, where $\mathrm{n}$ is the number of

234 carbon atoms in the free FA (Abrajano et al. 1994). The average $\delta^{13} \mathrm{C}$ value $(-39.6 \%$ ) was

235

calculated for the methyl-derived carbon based on the difference between the $\delta^{13} \mathrm{C}$ values of

236 the corresponding free FA and their respective FAME and this value was used to correct the

237 FAME $\delta^{13} \mathrm{C}$ by rearranging the above equation. Further studies found no kinetic isotope

238 effect associated to trans-esterification (Budge et al. 2008; Graham et al. 2014), thus this

239 aspect was not considered for $\delta^{13} \mathrm{C}$ analysis.

\section{Analytical error}

241 The analytical error (consisting of the SD of 10 analyses of the C16:0 FA laboratory standard

242 interspersed during the samples run) was $0.2 \%$. Therefore the analytical precision was

243 estimated to be $\leq 0.2 \%$.

tests with Bonferroni's adjustment method were performed. The isotopic variation in bivalve muscles was compared among stations by Kruskal-Wallis (KW) tests followed by Conover-

250 Iman multiple comparisons. Only the FA $>0.5 \%$ of total FA were considered to compare the

251 dissimilarity among stations, by a permutational variance analyses (PERMANOVA).

252 Subsequently, a test of similarity percentages analyses (SIMPER) was carried out to assess

253 the most discriminant FA responsible of the difference among stations (>80\%). Each FA

254 accounting for $>80 \%$ of dissimilarity among stations, and presenting an abundance 
255 permitting its detection in CSIA in all DG samples, was accounted. For that, one-way analysis 256 of variance (ANOVA) followed by Tukey's HSD, or KW tests followed by Conover-Iman 257 multiple comparison were carried out to compare the difference of their percentage of 258 neutral lipids, and their respective $\delta^{13} \mathrm{C}$ values, between the individuals from the three 259 stations. All statistical analyses and graphics were performed with the free software R (Core 260 Team 2017), with R Version 3.4.1 (2017 06 30). 
262

263

264

265

266

267

268

269

270

271

272

273

274

275

276

277

278

279

280

281

282

283

284

285

\section{Results}

Stable isotopes analyses

No significant differences in bulk $\delta^{13} \mathrm{C}$ values were observed in bivalve muscles between the different stations ( $\mathrm{KW}$ test, $\mathrm{H} 25=2.12, \mathrm{P}=0.35$ ). In contrast, a significant $\delta^{15} \mathrm{~N}$ difference was observed (KW test, H25 = 17.71, P < 0.001) (Fig. 2). Individuals from stations 1 and 2 displayed similar $\delta^{15} \mathrm{~N}$ (8.3\%o and 8.5\%o, respectively) (Fig. 2), while station 3 was ${ }^{15} \mathrm{~N}$ depleted (7.2\%o). For logistical reasons, only two replicates of POM and SOM could be sampled per site, which could not allow to statistically compare the results for these potential food sources. The pattern observed in POM was the same as observed for bivalve muscles with stations 1 and 2 being ${ }^{15} \mathrm{~N}$ enriched compared to station 3 (from $6.5 \%$ and 6.9\%o for stations 1 and 2 respectively, to $4 \%$ at station 3) (Fig. 2). The POM $\delta^{13} \mathrm{C}$ value sampled outside the lagoon $(-22.8 \%$ ) was slightly lower than at stations 2 and $3(-21.1 \%$ o and $-20.9 \%$, respectively). SOM displayed quite a different spatial pattern than the one observed for POM, with station 1 being ${ }^{15} \mathrm{~N}$ enriched and ${ }^{13} \mathrm{C}$ depleted $\left(\delta^{15} \mathrm{~N}=7.3 \%\right.$, $\delta{ }^{13} \mathrm{C}=-$ $14.5 \%$ ) compared to the two inner stations 2 and $3\left(\delta^{15} \mathrm{~N}=5.2 \%\right.$ and $4.6 \%$, $\delta^{13} \mathrm{C}=-10.2 \%$ o and $-13 \%$, respectively). Both samples of Zostera marina were ${ }^{13} \mathrm{C}$ enriched $(-10.0 \%$ for fresh eelgrass and $-11.2 \%$ for detrital eelgrass) compared to other samples. Fresh eelgrass displayed higher $\delta^{15} \mathrm{~N}$ than detrital eelgrass (5.6\%o and 1.8\%o, respectively) (Fig. 2).

\section{Fatty acids composition}

The FA composition of neutral lipids of DG varied significantly among stations (PERMANOVA, $F=48.76, P<0.001)$. Individuals from stations 1 and 2 , the closest to the mouth of the bay, were characterized by higher contents of $14: 0,20: 4 n-6$, and the diatom biomarkers $16: 1 n-7$ and 20:5n-3 than individuals from station 3 (ANOVA or KW tests followed by post-hoc; Table 
286

287

288

289

290

291

292

293

294

295

296

297

298

299

300

301

302

303

304

305

306

307

308

309

1). The PUFA 22:6n-3 was slightly more abundant in individuals from station $1(12.1 \%)$ than

in those from station $2(11.4 \%)$ and station 3 (10.5\%) (Table 1). The DG of individuals from the most inner station in the lagoon (station 3) had significantly higher contents of C18-FA (18:0, 18:1n-9, 18:3n-3, and 18:4n-3) and C16-FA (ANOVA or KW tests followed by post-hoc;

Table1).

Some FA in POM samples presented the same spatial variations than in bivalve DG, in particular 16:1n-7 that presented higher proportions at the external station (Table 2), and 18:4n-3 that showed higher values at the inner station (Table 2). When compared to bivalve DG, the PUFA 18:4n-3 and 20:5n-3 in POM were similar along the sampled transect (Table 2), and the $18: 1 n-9$ content was lower at station 2 and 3 ( $3 \%$ and $2.8 \%$, respectively) compared to station 1 (5.2\%) (Table 2).

\section{Compound-specific isotopic analyses}

The $\delta^{13} \mathrm{C}$ values of almost all selected FA of bivalve DG differed significantly among stations (ANOVA or KW tests followed by post-hoc; Table 1), with station 3 being different from stations 1 and 2, except for 20:4n-6, 20:5n-3 and 18:1n-7 (Table 1, Fig. 3). The differences among stations were significant for most FA, however, the range of variation did not exceed $1 \%$ o for some FA, such as $16: 1 \mathrm{n}-7$ (from $-27 \%$ o at the external station, to $-25.9 \%$ o at the inner station; Table 1), and 20:5n-3 at station $2(-26.9 \%$ ) differed significantly from station 3 (-27.6\%; Table 1) (Fig. 3). The variability of $\delta^{13} \mathrm{C}$ values of $18: 1 n-9+18: 3 n-3$ was $1.9 \%$ (Fig. 3), ranging from $-29.7 \%$ (station 1 ) to $-29.1 \%$ (station 2 ), and finally to $-31.0 \%$ o (station 3; Table 1). Because these FA coeluted on the apolar column used for GC-C-IRMS analysis, they were reported jointly. The $\delta^{13} \mathrm{C}$ values of $18: 4 n-3$ displayed the highest range of variability (2.3\%o) (Fig. 3), ranging from $-29.2 \%$ at stations 1 and 2 to $-31.5 \%$ o at station 3 
310 (Table 1). Finally, 22:6n-3 varied in its $\delta^{13} \mathrm{C}$ values among the stations (1.8\%; Fig. 3) with

311 higher $\delta^{13} \mathrm{C}$ values at the external stations 1 and 2 (-26.1\%o and $-26.9 \%$, respectively)

312 compared to lower $\delta^{13} \mathrm{C}$ values at the inner station $3(-27.5 \%)$ (Table 1$)$. For C18 FA (18:1n-9,

$31318: 3 n-3,18: 4 n-3)$ and $22: 6 n-3$ of bivalve DG, samples from station 3 were always more

314 depleted in ${ }^{13} \mathrm{C}$ compared to other stations (Table 1 and Fig. 3).

315 Similar trends in isotopic variability of FA were found in POM samples than in bivalve DG,

316 with $18 \mathrm{C}$ and $22: 6 \mathrm{n}-3$ always more depleted in ${ }^{13} \mathrm{C}$ with increasing distance from the mouth

317 of the lagoon (Table 2). For example, the $\delta^{13} \mathrm{C}$ values of $18: 4 \mathrm{n}-3$ were similar at station 1 (-

$31831.6 \%$ ) and $2(-31.4 \%$ ) and more depleted at station $3(-32.3 \%$; Table 2$)$, and the 22:6n-3

319 showed $\delta^{13} \mathrm{C}$ depleted values along the transect (from $-25.6 \%$ and $-27.5 \%$ at stations 1 and

3202 to $-34.9 \%$ at station 3; Table 2). Like in DG samples, both FA, $16: 1 n-7$ and $20: 5 n-3$ were ${ }^{13} \mathrm{C}$

321 enriched at the internal station (Table 2) in POM samples. Indeed, 16:1n-7 and 20:5n-3

322 showed respectively $\delta^{13} \mathrm{C}$ from $-26.7 \%$ and $-29.5 \%$ at the external station, to $-25.8 \%$ and -

$32328.7 \%$ at the station near to the mouth, and to $-25.7 \%$ ond $-27.5 \%$ o at the inner station

324 (Table 2). 


\section{Discussion}

Results from this study suggest that organic matter from the ocean is transported into the lagoon, contributing to the primary production and to the diet of benthic filter feeders. The CSIA on FA data indicate that diatoms (indicated by $16: 1 n-7$ and $20: 5 n-3$ ) assimilated by bivalves have a very similar marine origin throughout the lagoon, according to their comparable $\delta^{13} \mathrm{C}$ values among stations. Moreover, results also demonstrate that a diversity of heterotrophic flagellates, characterized by higher contents of 18 carbon FA, and 22:6n-3 may also enter the diet of bivalves. The variable $\delta^{13} \mathrm{C}$ values of these FA among stations suggest that their origin varies according to the location within the lagoon, and depleted values at the inner station indicate an influence of local processes in the diet of these consumers.

The most striking result from bulk SI analysis of bivalve muscles and POM was the significant

${ }^{15} \mathrm{~N}$ enrichment observed near the entrance of the lagoon, with individuals from stations 1 and 2 displaying similar $\delta^{15} \mathrm{~N}$ values that were higher than in the inner bay. This reveals an oceanic influence, and particularly the contribution of ${ }^{15} \mathrm{~N}$ oceanic inputs to the diet of bivalves near the entrance of the lagoon, but also that such dietary influence of the ocean did not extend to the innermost part of the lagoon. This oceanic influence may be explained by active wind-driven seasonal upwelling occurring outside the lagoon from April to June (Ibarra-Obando et al. 2001; Du et al. 2015). It has been suggested that water masses containing upwelled biological material could be transported into coastal lagoons of the Pacific coast of Baja California (Zaytsev 2003), promoting primary production and potentially affecting their trophic functioning. The hypothesis that upwelled waters affect the diet of bivalves inside the lagoon is based on the fact that during upwelling conditions, the biomass of large phytoplankton increases (Taylor and Landry 2018), and as upwelled nitrate is rapidly 
350

351

352

consumed by phytoplankton (O'Reilly et al. 2002), its $\delta^{15} \mathrm{~N}$ increases. Although coastal upwelling influence on the studied lagoon was not supported by chlorophyll $a$ or temperature data, such high $\delta^{15} \mathrm{~N}$ with no changes in $\delta^{13} \mathrm{C}$ have been reported in various systems under upwelling influence worldwide (O'Reilly et al. 2002; Hill and McQuaid 2008;

Reddin et al. 2015).

The spatial differences found in the FA composition of neutral lipids in the DG of bivalves indicates a change in the proportion and possibly in the nature of food sources with increasing distance from the mouth of the lagoon. The DG at the entrance of the lagoon (stations 1 and 2) had higher 16:1n-7 and 20:5n-3 contents when compared to individuals from the inner station (station 3), indicating a higher contribution of diatoms in their diet (Parrish et al. 2000; Alfaro et al. 2006). A previous study revealed that during the late spring, diatoms are the dominant phytoplankton taxa found in the Northern California current (Du et al. 2015). The higher importance of diatoms in the diet of bivalves near the entrance of the lagoon therefore supports the influence of oceanic primary production. Individuals from the inner station had lower contents of these two FA, suggesting a dilution of oceanic inputs further into the lagoon. The importance of $22: 6 n-3$ in DG of individuals at the external station suggests that dinoflagellates also represent an important dietary contribution of Spondylus crassisquama (Parrish et al. 2000). This contribution decreases slightly with increasing distance from the mouth of the lagoon, being the lowest at the internal station, suggesting a decreasing contribution of dinoflagellates to this station. However, the high abundance of 18:4n-3, another dinoflagellate marker (Kharlamenko et al. 2001; Bachok et al. 2003; Nerot et al. 2015), at the inner station (station 3) suggests the opposite. Such conflicting information by these two dinoflagellate markers may indicate different assemblages being assimilated by bivalves in the lagoon, but such change in dietary 
374 biomarkers does not necessarily suggest any shift in contribution of dinoflagellates to the

375 diets of these consumers. Bivalves from the inner bay were also characterized by higher C18-

376 FA contents (18:1n-9, 18:3n-3). These FA can be characteristic of different dietary sources,

377 such as seagrass (Kharlamenko et al. 2001) or heterotrophic flagellates constituting microbial

378 food webs (Zhukova 1991). Although seagrass beds are known to be a source of dissolved

379 organic matter (DOM; Fenton and Ritz 1988), bivalve muscles were too ${ }^{13} \mathrm{C}$ depleted as

380 compared to seagrass $\delta^{13} \mathrm{C}$ to be in accordance with a significant trophic contribution of

381 Zostera marina. Consequently, the abundance of these FA likely reflects the contribution of

382 heterotrophic microorganisms (i.e. bacteria, ciliates, flagellates, dinoflagellates), relying on

383 locally produced DOM, to the diet of bivalves. This highlights a higher diversity of food

384 sources for bivalves at the internal station than for those submitted to oceanic influences

385 and shows that diet source variation within this and possibly other lagoons is based on

386 allochthonous and autochthonous contribution. Such various diet sources could also present

387 differences in terms of quality and quantity, which consequently impact bivalve stocks and

388 consequently fisheries. More detailed understanding of spatio-temporal dynamics of these

389 food resources would lead to a better management of bivalve stocks in the Ojo de Liebre

390 lagoon and elsewhere.

391 Inferring diet composition based on CSIA requires FA-specific fractionation coefficients,

392 which are not available for our species, and would require extensive laboratory experiments

393 (Ruess and Chamberlain 2010; Bec et al. 2011). Consequently, our approach did not aim to

394 characterize the accuracy of food sources retention by bivalves, but to scrutinize the trophic

395 spatial variability in an effort to provide evidence of a different spatial origin of the diets for

396 this consumer (Ramos et al. 2003; Van den Meersche et al. 2004). Although no difference in

397 bulk $\delta^{13} \mathrm{C}$ values was observed in muscles of individuals from the different stations, CSIA 
398

399

400

401

402

403

404

405

406

407

408

409

410

411

412

413

414

415

416

417

418

419

420

421

detect the isotopic composition of FA that may indicate source-specific differences of FA (Budge et al. 2008; Colombo et al. 2016). Some differences were observed in the range of variation in $\mathrm{FA} \delta^{13} \mathrm{C}$ along the transect depending on biomarkers considered (diatoms vs heterotrophic flagellates). In DG neutral lipids, diatom biomarkers (16:1n-7 and 20:5n-3) displayed the smallest range of variation among the three stations $(\leq 1 \% \circ)$, which is of little ecological value. The spatial consistency in the $\delta^{13} \mathrm{C}$ values of these diatom biomarkers suggests that diatoms assimilated by bivalves have all oceanic origin throughout the bay. Therefore, it seems that phytoplankton of local origin (produced within the lagoon) is of relatively little dietary importance for S. crassisquama. The C18-FA 18:1n-9 and 18:3n-3 were both considered to reveal the contribution of microheterotrophs (flagellates, ciliates, see above). Even if the three stations presented significant differences in their $\delta^{13} \mathrm{C}$ for $18: 1 \mathrm{n}-9$ and $18: 3 n-3$, stations 1 and 2 displayed very similar $\delta^{13} \mathrm{C}$ values (only differed by $0.6 \%$ ), while station 3 was depleted in ${ }^{13} \mathrm{C}$ by $1.9 \%$ o compare to the other stations. This difference suggests that the origin of these microheterotrophs differed within the lagoon.

Microheterotrophs are central elements of microbial food webs, feeding on bacteria and other small unicellular organisms, and ultimately relying on DOM (Azam et al. 1983). The ${ }^{13} \mathrm{C}$ depletion observed at the inner station suggests a local source of DOM, which is of primary importance for bivalves in the lagoon. Although the lagoon of Ojo de Liebre hosts one of the largest eelgrass bed of the Northern Pacific (Cabello-Pasini et al. 2003), a seagrass-derived DOM seems unlikely because seagrass is usually ${ }^{13} \mathrm{C}$ enriched compared to other marine primary producers (Hemminga and Mateo 1996), which was also observed in the present study. The possible DOM release from the sediment is also not in agreement with $\delta^{13} \mathrm{C}$ measured for these FA (around $-24.5 \%$ in SOM). In fact, such ${ }^{13} \mathrm{C}$-depleted values in coastal environments are usually associated with red algae, which can be extremely low in $\delta^{13} \mathrm{C}$ 
422 (Raven et al. 2002). Although no extensive population of such algae was observed during

423 sampling, it is possible that such populations exist in the inner bay, supplying a pool of

424 dissolved organic carbon that is subsequently trophically transferred to bivalves.

425 Dinoflagellate FA biomarkers (18:4n-3 and 22:6n-3) had a very similar spatial distribution

426 pattern as observed for biomarkers of other microheterotrophs (18:1n-9 and 18:3n-3), with

427 a marked ${ }^{13} \mathrm{C}$ depletion at the inner station. Therefore, in contrast to diatoms, dinoflagellates

428 entering the diet of bivalves do not seem to be of marine origin throughout the lagoon. The

429 similarity observed between the CSIA in microheterotrophs and dinoflagellates might

430 suggest that the same factors affect the SI composition of these two possible food sources.

431 In fact, although dinoflagellates are usually described as primary producers, heterotrophy is

432 a widespread pattern in this group (Jeong et al. 2010). Based on these results, it is possible

433 that dinoflagellates assimilated by S. crassisquama in the inner part of the lagoon may rely

434 on heterotrophy, emphasizing a potentially important role of the microbial food web in this

435 enclosed ecosystem.

436

437 Conclusion

438 The use of CSIA provided a new scale of complexity in the diet of Spondylus crassisquama in

439 the Ojo de Liebre lagoon. Although dietary diatoms retained in bivalves appeared to have

440 the same oceanic origin throughout the lagoon, this study indicates that the heterotrophic

441 component of bivalve diet varies spatially in the lagoon, highlighting an influence of local

442 processes in the diet of these consumers. The combination of the three methods used here

443 showed to be complementary, resulting in a more informative analysis of spatial feeding

444 ecology of this and likely also other lagoons. The lower $\delta^{13} \mathrm{C}$ observed at the most inner 
445 station could not be explained in this study, although any potential role of seagrass in 446 providing DOM for the associated microbial food web could be discarded based on different 447 SI data. Further research is warranted to identify how the origin of basal resources vary and 448 support food webs in lagoons and to better understand the quantitative importance of 449 dietary sources for bivalves. 
450

451

452

453

454

455

456

457 Arredondo Vega, for the laboratory facilities provided for the preparation of samples at the

458 CIBNOR La Paz. Authors address their thanks to the Reserva de la biosfera desierto de "el

459 Vizcaino" for their help and support in carrying out sampling for this study. Authors would

460 like to thank Aurelien Boye for his precious help and advices about statistical analyses.

461 Authors also thank Pr. Sandra Shumway and an anonymous reviewer, for their help in

462 improving this paper.

463

464

465

466

467

468

469

470 Compliance with Ethical Standards

471 Conflict of interest 
472 The authors declare that they have no conflict of interest.

\section{Ethical approval}

474 All applicable international, national and/or institutional guidelines for the care and use of

475 bivalves Spondylus crassisquama were followed. The individuals of S. crassisquama have

476 been sampled under the permit PRMN/DGOPA-011/2017, delivered by the Mexican

477 government. 
478

479

480

481

482

483

484

485

486

487

488

489

490

491

492

493

494

495

\section{References}

Abrajano TA, Murphy DE, Fang J, Comet $\mathrm{P}$, Brooks JM (1994) ${ }^{13} \mathrm{C}^{12} \mathrm{C}$ ratios in individual fatty acids of marine mytilids with and without bacterial symbionts. Org Geochem 21:611-617. doi: $10.1016 / 0146-6380(94) 90007-8$

Alfaro AC, Thomas F, Sergent L, Duxbury M (2006) Identification of trophic interactions within an estuarine food web (northern New Zealand) using fatty acid biomarkers and stable isotopes. Estuar Coast Shelf Sci 70:271-286. doi: 10.1016/j.ecss.2006.06.017

Allan EL, Ambrose ST, Richoux NB, Froneman PW (2010) Determining spatial changes in the diet of nearshore suspension-feeders along the South African coastline: Stable isotope and fatty acid signatures. Estuar Coast Shelf Sci 87:463-471. doi: 10.1016/j.ecss.2010.02.004 Azam F, Fenchel T, Field JG, Gray JS, Meyer-Reil LA, Thingstad F (1983) The ecological role of water-column microbes in the sea. Mar Ecol Prog Ser 257-263.

Bachelet G, De Montaudouin X, Auby I, Labourg P-J (2000) Seasonal changes in macrophyte and macrozoobenthos assemblages in three coastal lagoons under varying degrees of eutrophication. ICES J Mar Sci 57:1495-1506.

Bachok Z, Mfilinge PL, Tsuchiya M (2003) The diet of the mud clam Geloina coaxans (Mollusca, Bivalvia) as indicated by fatty acid markers in a subtropical mangrove forest of Okinawa, Japan. J Exp Mar Biol Ecol 292:187-197. doi: 10.1016/S0022-0981(03)00160-6

Bec A, Perga M-E, Koussoroplis A, Bardoux G, Desvilettes C, Bourdier G, Mariotti A (2011) Assessing the reliability of fatty acid-specific stable isotope analysis for trophic studies. Methods Ecol Evol 2:651-659. doi: 10.1111/j.2041-210X.2011.00111.x 
499

500

501

502

503

504

505

506

507

Budge SM, Iverson SJ, Koopman HN (2006) Studying trophic ecology in marine ecosystems using fatty acids: a primer on analysis and interpretation. Mar Mammal Sci 22:759-801. doi: 10.1111/j.1748-7692.2006.00079.x

Budge SM, Wooller MJ, Springer AM, Iverson SJ, McRoy CP, Divoky GJ (2008) Tracing carbon flow in an arctic marine food web using fatty acid-stable isotope analysis. Oecologia 157:117-129.

Cabello-Pasini A, Muñiz-Salazar R, Ward DH (2003) Annual variations of biomass and photosynthesis in Zostera marina at its southern end of distribution in the North Pacific. Aquat Bot 76:31-47. doi: 10.1016/S0304-3770(03)00012-3

Carlier A, Riera P, Amouroux J-M, Bodiou J-Y, Desmalades M, Grémare A (2008) Food web structure of two Mediterranean lagoons under varying degree of eutrophication. J Sea Res 60:264-275. doi: 10.1016/j.seares.2008.10.006

Clavier J, Chauvaud L, Amice E, Lazure P, Van Der Geest M, Labrosse P, Diagne A, Carlier A, Chauvaud S (2014) Benthic metabolism in shallow coastal ecosystems of the Banc d'Arguin, Mauritania. Mar Ecol Prog Ser 501:11-23.

Colombo SM, Parrish CC, Whiticar MJ (2016) Fatty acid stable isotope signatures of molluscs exposed to finfish farming outputs. Aquac Environ Interact 8:611-617.

Core Team R (2017) R: A language and environment for statistical computing. R Foundation for Statistical Computing, Vienna, Austria. URL https://www.R-project.org/.

\section{Dalsgaard J, St. John M, Kattner G, Müller-Navarra D, Hagen W (2003) Fatty acid trophic} markers in the pelagic marine environment. Adv Mar Biol 46:225-340. doi: 10.1016/S00652881(03)46005-7 
521 Du X, Peterson W, O'Higgins L (2015) Interannual variations in phytoplankton community

522 structure in the northern California Current during the upwelling seasons of 2001-2010. Mar

523 Ecol Prog Ser 519:75-87.

524 Falkowski PG (1991) Species variability in the fractionation of ${ }^{13} \mathrm{C}$ and ${ }^{12} \mathrm{C}$ by marine

525 phytoplankton. J Plankton Res 13:21-28. doi: 10.1093/oxfordjournals.plankt.a042367

526 Fenton GE, Ritz DA (1988) Changes in carbon and hydrogen stable isotope ratios of

527 macroalgae and seagrass during decomposition. Estuar Coast Shelf Sci 26:429-436.

528 Folch J, Lees M, Sloane-Stanley GH (1957) A simple method for the isolation and purification 529 of total lipids from animal tissues. J Biol Chem 226:497-509.

530 France RL (1995) Carbon-13 enrichment in benthic compared to planktonic algae: foodweb 531 implications. Mar Ecol Prog Ser 124:307-312.

532 Fry B (1988) Food web structure on Georges Bank from stable C, N, and S isotopic

533 compositions. Limnol Oceanogr 33:1182-1190. doi: 10.4319/lo.1988.33.5.1182

534 Gaillard B, Meziane T, Tremblay R, Archambault P, Blicher ME, Chauvaud L, Rysgaard S, 535 Olivier F (2017) Food resources of the bivalve Astarte elliptica in a sub-Arctic fjord: a multi536 biomarker approach. Mar Ecol Prog Ser 567:139-156.

537 Graham C, Oxtoby L, Wang SW, Budge SM, Wooller MJ (2014) Sourcing fatty acids to juvenile 538 polar cod (Boreogadus saida) in the Beaufort Sea using compound-specific stable carbon 539 isotope analyses. Polar Biol 37:697-705.

540 Hemminga MA, Mateo MA (1996) Stable carbon isotopes in seagrasses: variability in ratios 541 and use in ecological studies. Mar Ecol Prog Ser 140:285-298. 
542

Hill JM, McQuaid CD (2008) $\delta^{13} \mathrm{C}$ and $\delta^{15} \mathrm{~N}$ biogeographic trends in rocky intertidal

543

544 communities along the coast of South Africa: Evidence of strong environmental signatures.

Estuar Coast Shelf Sci 80:261-268. doi: 10.1016/j.ecss.2008.08.005

545 Ibarra-Obando SE, Camacho-Ibar VF, Carriquiry JD, Smith SV (2001) Upwelling and lagoonal

546 ecosystems of the dry Pacific coast of Baja California. In: Coastal Marine Ecosystems of Latin

547 America. Springer, pp 315-330

548 Jaschinski S, BrepohI DC, Sommer U (2008) Carbon sources and trophic structure in an

549 eelgrass Zostera marina bed, based on stable isotope and fatty acid analyses. Mar Ecol Prog

550 Ser 358:103-114.

551 Jeong HJ, Du Yoo Y, Kim JS, Seong KA, Kang NS, Kim TH (2010) Growth, feeding and ecological 552 roles of the mixotrophic and heterotrophic dinoflagellates in marine planktonic food webs.

553 Ocean Sci J 45:65-91.

554 Kainz M, Lucotte M, Parrish CC (2002) Methyl mercury in zooplankton the role of size,

555 habitat, and food quality. Can J Fish Aquat Sci 59:1606-1615.

556 Kelly JR, Scheibling RE (2012) Fatty acids as dietary tracers in benthic food webs. Mar Ecol

557 Prog Ser 446:1-22.

558 Kharlamenko VI, Kiyashko SI, Imbs AB, Vyshkvartzev DI (2001) Identification of food sources

559 of invertebrates from the seagrass Zostera marina community using carbon and sulfur stable

560 isotope ratio and fatty acid analyses. Mar Ecol Prog Ser 220:103-117.

561 Layman CA, Araujo MS, Boucek R, Hammerschlag-Peyer CM, Harrison E, Jud ZR, Matich P, 562 Rosenblatt AE, Vaudo JJ, Yeager LA (2012) Applying stable isotopes to examine food-web 563 structure: an overview of analytical tools. Biol Rev 87:545-562. 
564 Le Grand FL, Soudant P, Siah A, Tremblay R, Marty Y, Kraffe E (2014) Disseminated Neoplasia

565 in the soft-shell Clam Mya arenaria: membrane lipid composition and functional parameters

566 of circulating cells. Lipids 49:807-818. doi: 10.1007/s11745-014-3917-4

567 Lorrain A, Paulet Y-M, Chauvaud L, Savoye N, Donval A, Saout C (2002) Differential $\delta^{13} C$ and

$568 \delta^{15} \mathrm{~N}$ signatures among scallop tissues: implications for ecology and physiology. J Exp Mar

569 Biol Ecol 275:47-61. doi: 10.1016/S0022-0981(02)00220-4

570 Marchais V, Schaal G, Grall J, Lorrain A, Nerot C, Richard P, Chauvaud L (2013) Spatial

571 variability of stable isotope Ratios in Oysters (Crassostrea gigas) and primary producers

572 along an estuarine gradient (Bay of Brest, France). Estuaries Coasts 36:808-819. doi:

$573 \quad 10.1007 / \mathrm{s} 12237-012-9584-x$

574 Nerot C, Meziane T, Schaal G, Grall J, Lorrain A, Paulet Y-M, Kraffe E (2015) Spatial changes in

575 fatty acids signatures of the great scallop Pecten maximus across the Bay of Biscay

576 continental shelf. http://ac.els-cdn.com.scd-proxy.univ-brest.fr/S0278434315300522/1-s2.0-

577 S0278434315300522-main.pdf?_tid=cc01133c-2f39-11e7-8950-

578 00000aab0f02\&acdnat=1493731274_d207b602cfd94a22be277a4effaa33b7. Accessed 2

579 May 2017

580 Nixon SW (1982) Nutrient dynamics, primary production and fisheries yields of lagoons.

581 Oceanol Acta Spec Issue 357-371.

582 O'Reilly CM, Hecky RE, Cohen AS, Plisnier P-D (2002) Interpreting stable isotopes in food

583 webs: Recognizing the role of time averaging at different trophic levels. Limnol Oceanogr

584 47:306-309. doi: 10.4319/lo.2002.47.1.0306 
585

586

587 chemistry. Springer, pp 193-223

588

589

590

591

592

593 Geochem 34:195-207.

594 Raven JA, Johnston AM, Kübler JE, Korb R, Mclnroy SG, Handley LL, Scrimgeour CM, Walker 595 DI, Beardall J, Vanderklift M, Fredriksen S, Dunton KH (2002) Mechanistic interpretation of 596 carbon isotope discrimination by marine macroalgae and seagrasses. Funct Plant Biol

597 29:355-378. doi: 10.1071/pp01201

598 Reddin CJ, Docmac F, O'Connor NE, Bothwell JH, Harrod C (2015) Coastal upwelling drives 599 intertidal assemblage structure and trophic ecology. PloS One 10:e0130789.

600 Riera P (2007) Trophic subsidies of Crassostrea gigas, Mytilus edulis and Crepidula fornicata 601 in the Bay of Mont Saint Michel (France): a $\delta^{13} \mathrm{C}$ and $\delta^{15} \mathrm{~N}$ investigation. Estuar Coast Shelf Sci 602 72:33-41. doi: 10.1016/j.ecss.2006.10.002

603 Riera P, Richard P (1996) Isotopic determination of food sources of Crassostrea gigas along a 604 trophic gradient in the estuarine bay of Marennes-Oléron. Estuar Coast Shelf Sci 42:347-360.

605 Ruess L, Chamberlain PM (2010) The fat that matters: soil food web analysis using fatty acids 606 and their carbon stable isotope signature. Soil Biol Biochem 42:1898-1910. 
607 Schaal G, Nerot C, Grall J, Chouvelon T, Lorrain A, Mortillaro J-M, Savoye N, Brind'Amour A,

608 Paulet Y-M, Le Bris H (2016) Stable isotope ratios in bentho-demersal biota along a depth 609 gradient in the Bay of Biscay: a multitrophic study. Estuar Coast Shelf Sci 179:201-206. doi:

$610 \quad 10.1016 /$ j.ecss.2015.10.023

611 Taylor AG, Landry MR (2018) Phytoplankton biomass and size structure across trophic

612 gradients in the southern California Current and adjacent ocean ecosystems. Mar Ecol Prog 613 Ser 592:1-17.

614 Van den Meersche K, Middelburg JJ, Soetaert K, Van Rijswijk P, Boschker HT, Heip CH (2004)

615 Carbon-nitrogen coupling and algal-bacterial interactions during an experimental bloom:

616 modeling a 13C tracer experiment. Limnol Oceanogr 49:862-878.

617 Vuorio K, Meili M, Sarvala J (2006) Taxon-specific variation in the stable isotopic signatures $618\left(\delta^{13} \mathrm{C}\right.$ and $\left.\delta^{15} \mathrm{~N}\right)$ of lake phytoplankton. Freshw Biol 51:807-822.

619 Zaytsev (2003) Coastal upwelling activity on the Pacific shelf of the Baja California peninsula.

620 J Oceanogr 59:489-502.

621 Zhukova NV (1991) The pathway of the biosynthesis of non-methylene-interrupted dienoic 622 fatty acids in molluscs. Comp Biochem Physiol Part B Comp Biochem 100:801-804. 
624

625

626

628

630

631

632

634

636

638

639

640

641

642

643

644

\section{Table captions}

Table 1 - Neutral lipid fatty acid (FA) composition (mean \pm SD; mass $\%$ of total FA; $n=10$ )

and Compound Specific Isotopic analysis (CSIA) of neutral lipid FA (mean \pm SD; $\delta^{13} \mathrm{C} \%$; $n=5$ )

of Spondylus crassisquama digestive gland in June 2017, for the 3 stations (1, 2, and 3). Only the FA accounting for more than $80 \%$ of dissimilarity between stations (SIMPER test) and presenting the greatest abundance permitting their good detection in CSIA are shown.

Different letters indicate significant difference between the stations (ANOVA or KW tests followed by multiple comparison tests, at the significant level $\alpha<0.05) .{ }^{*}$ In CSIA, 18:1n-9 and $18: 1 \mathrm{n}-3$ are coeluted and $\delta^{13} \mathrm{C}$ value is presented in the same line.

Table 2 - Total fatty acid (FA) composition (mean; mass $\%$ of total FA; $n=2$ ) and Compound Specific Isotopic analysis (CSIA) of FA (mean; $\delta^{13} \mathrm{C} \%$; $n=2$ ) of potential food sources, for the 3 stations (1, 2, and 3). Only the FA accounting for more than $80 \%$ of dissimilarity between stations (SIMPER test) and presenting the greatest abundance permitting their good detection in CSIA are shown. NA: Not analyzed. *In CSIA, 18:1n-9 and 18:1n-3 are coeluted and $\delta^{13} \mathrm{C}$ value is presented in the same line. 
645 lagoon, respectively at $6.1 \mathrm{~km}$ and $15.5 \mathrm{~km}$ from the mouth of the lagoon. (Map modified 646 from Google earth).

647

648 Fig. 2 Stable Isotope $(\mathrm{SI})$ bi-plot $\left(\delta^{13} \mathrm{C}\right.$ and $\delta^{15} \mathrm{~N}$, mean values $\pm S D$ when $\left.n>2\right)$ of the adductor 649 muscles of Spondylus crassisquama and of its potential food sources, in June 2017, at the 3 650 sampled stations. Samples from station 1 are shown in dark blue, 2 in light blue, and 3 in 651 green. Bivalves are represented by squares, POM by circles, SOM by triangles, and eelgrass 652 by crosses ( ${ }^{*}$ fresh; $x$ detrital).

653

654 Fig. 3 Box plot of $\delta^{13} \mathrm{C}$ values (\%o; $\left.n=5\right)$ of some selected neutral lipid fatty acid (FA) of 655 Spondylus crassisquama digestive gland in June 2017 at each stations (1, 2, and 3). Only the 656 FA accounting for more than $80 \%$ of dissimilarity between stations, presented the greatest 657 abundance permitting their good detection in CSIA, and present in all samples are shown. 658 Different letters indicate significant difference between the stations (ANOVA or KW tests 659 followed by multiple comparison tests, at the significant level $\alpha<0.05)$. Samples from 660 station 1 are shown in dark blue, 2 in light blue, and 3 in green. 
Mathieu-Resuge, M., Schaal, G., Kraffe, E. et al. Mar Biol (2019) 166: 89. https://doi.org/10.1007/s00227-019-3535-z

Table 1

\begin{tabular}{|c|c|c|c|c|c|c|c|c|c|c|c|c|}
\hline & \multicolumn{6}{|c|}{ Fatty Acids (mass \% of neutral lipid FA) } & \multicolumn{6}{|c|}{ Compound Specific Isotopic Analysis $\left(\delta^{13} \mathrm{C} \%\right.$ ) } \\
\hline & Station 1 & & Station 2 & & Station 3 & & Station 1 & & Station 2 & & Station 3 & \\
\hline 14:0 & $5.8 \pm 0.6$ & A & $6.1 \pm 0.5$ & A & $4.2 \pm 0.3$ & B & $-28.2 \pm 0.2$ & a & $-28.3 \pm 0.2$ & a & $-29.7 \pm 0.3$ & $b$ \\
\hline 16:0 & $21.6 \pm 0.4$ & B & $21.9 \pm 0.9$ & B & $23.9 \pm 0.9$ & A & $-27.5 \pm 0.3$ & a & $-27.1 \pm 0.1$ & a & $-29.9 \pm 0.6$ & $b$ \\
\hline 18:0 & $4.1 \pm 0.5$ & B & $3.9 \pm 0.4$ & B & $5.6 \pm 0.5$ & A & $-26.8 \pm 0.3$ & a & $-26.4 \pm 0.2$ & a & $-28.3 \pm 0.4$ & b \\
\hline $16: 1 n-7$ & $10.1 \pm 0.8$ & A & $10.5 \pm 0.8$ & A & $5.0 \pm 0.2$ & B & $-27.0 \pm 0.2$ & $b$ & $-26.6 \pm 0.1$ & b & $-25.9 \pm 0.4$ & a \\
\hline $18: 1 n-7$ & $2.8 \pm 0.1$ & & $2.8 \pm 0.2$ & & $2.8 \pm 0.1$ & & $-27.5 \pm 0.5$ & & $-27.2 \pm 0.6$ & & $-27.8 \pm 0.4$ & \\
\hline $18: 1 n-9 *$ & $3.4 \pm 0.1$ & B & $3.3 \pm 0.3$ & B & $4.8 \pm 0.4$ & A & $-29.7 \pm 0.3$ & a & $-29.1 \pm 0.2$ & b & $-31.0 \pm 0.2$ & c \\
\hline $18: 3 n-3^{*}$ & $3.4 \pm 0.1$ & B & $3.3 \pm 0.1$ & B & $5.3 \pm 0.2$ & A & & & & & & \\
\hline $18: 4 n-3$ & $5.1 \pm 0.4$ & B & $5.4 \pm 0.5$ & B & $6.6 \pm 0.4$ & A & $-29.2 \pm 0.9$ & a & $-29.2 \pm 0.6$ & a & $-31.5 \pm 1.1$ & $\mathrm{~b}$ \\
\hline $20: 4 n-6$ & $1.7 \pm 0.1$ & A & $1.6 \pm 0.1$ & A & $1.0 \pm 0.1$ & B & $-26.7 \pm 0.4$ & & $-26.8 \pm 0.6$ & & $-26.3 \pm 1.5$ & \\
\hline $20: 5 n-3$ & $12.0 \pm 0.3$ & A & $11.4 \pm 0.8$ & A & $8.6 \pm 1.2$ & B & $-27.1 \pm 0.3$ & $a b$ & $-26.9 \pm 0.4$ & a & $-27.6 \pm 0.5$ & $\mathrm{~b}$ \\
\hline $22: 6 n-3$ & $12.1 \pm 1.0$ & A & $11.4 \pm 0.8$ & $A B$ & $10.5 \pm 0.9$ & B & $-26.1 \pm 0.2$ & a & $-25.7 \pm 0.4$ & a & $-27.5 \pm 0.8$ & b \\
\hline
\end{tabular}




\begin{tabular}{|c|c|c|c|c|c|c|c|c|c|c|c|c|c|c|c|c|}
\hline & \multicolumn{8}{|c|}{ Fatty Acids (mass\% of total lipid FA) } & \multicolumn{8}{|c|}{ Compound Specific Isotopic Analysis ( $\delta^{13} \mathrm{C} \%$ ) } \\
\hline & \multicolumn{3}{|c|}{ POM } & \multicolumn{3}{|c|}{ SOM } & \multicolumn{2}{|c|}{ Eelgrass } & \multicolumn{3}{|c|}{ POM } & \multicolumn{3}{|c|}{ SOM } & \multicolumn{2}{|c|}{ Eelgrass } \\
\hline & $\begin{array}{c}\text { Station } \\
1\end{array}$ & $\begin{array}{c}\text { Station } \\
2\end{array}$ & $\begin{array}{c}\text { Station } \\
3\end{array}$ & $\begin{array}{c}\text { Station } \\
1\end{array}$ & $\begin{array}{l}\text { Station } \\
2\end{array}$ & $\begin{array}{c}\text { Station } \\
3\end{array}$ & Fresh & Detrital & $\begin{array}{c}\text { Station } \\
1\end{array}$ & $\begin{array}{c}\text { Station } \\
2\end{array}$ & $\begin{array}{c}\text { Station } \\
3\end{array}$ & $\begin{array}{c}\text { Station } \\
1\end{array}$ & $\begin{array}{c}\text { Station } \\
2\end{array}$ & $\begin{array}{c}\text { Station } \\
3\end{array}$ & Fresh & Detrital \\
\hline 14:0 & 9.7 & 11.4 & 7.2 & 2.6 & 3.8 & 3.2 & 0.8 & 1.9 & -26.7 & -25.9 & -27.7 & NA & NA & NA & -18.9 & -26.4 \\
\hline 16:0 & 21.3 & 25.0 & 26.0 & 16.3 & 22.2 & 20.6 & 21.8 & 25.6 & -30.5 & -31.1 & -34.5 & -27.2 & -23.6 & -23.3 & -17.5 & -22.3 \\
\hline 18:0 & 6.4 & 6.1 & 4.5 & 6.4 & 6.1 & 6.3 & 1.9 & 2.6 & -29.0 & -29.8 & -30.8 & -30.1 & -27.7 & -26.6 & -16.4 & -25.3 \\
\hline $16: 1 n-7$ & 6.1 & 5.4 & 5.1 & 7.3 & 12.0 & 8.3 & 0.4 & 1.0 & -26.7 & -25.8 & -25.7 & -23.5 & -23.4 & -22.2 & -15.8 & -17.2 \\
\hline $18: 1 n-7$ & 3.1 & 2.6 & 3.0 & 6.7 & 3.9 & 5.2 & 0.4 & 1.4 & -23.5 & -23.1 & -20.9 & -21.1 & -20.1 & -19.4 & NA & NA \\
\hline $18: 1 n-9 *$ & 5.2 & 3.0 & 2.8 & 4.1 & 3.0 & 4.3 & 1.4 & 1.9 & -28.4 & -29.9 & -30.8 & -25.8 & -24.6 & -24.5 & NA & NA \\
\hline $18: 3 n-3 *$ & 2.2 & 2.5 & 3.3 & 1.8 & 0.9 & 1.2 & 38.3 & 29.7 & & & & & & & & \\
\hline $18: 4 n-3$ & 3.6 & 3.8 & 3.9 & 0.9 & 1.3 & 1.5 & 0.1 & 0.3 & -31.6 & -31.4 & -32.3 & NA & NA & NA & NA & NA \\
\hline $20: 4 n-6$ & 0.2 & 0.1 & 0.1 & 0.4 & 0.2 & 0.2 & 0.1 & 0.5 & NA & NA & NA & -26.0 & -23.2 & -23.3 & NA & NA \\
\hline $20: 5 n-3$ & 5.5 & 5.3 & 5.3 & 7.4 & 7.2 & 8.8 & 0.2 & 1.5 & -29.5 & -28.7 & -27.5 & -25.4 & -21.2 & -22.8 & NA & NA \\
\hline $22: 6 n-3$ & 7.9 & 7.1 & 4.3 & 5.8 & 2.7 & 3.4 & 0.3 & 0.7 & -25.6 & -27.5 & -34.9 & -25.1 & -21.7 & -24.4 & NA & NA \\
\hline
\end{tabular}


1 Fig. 1

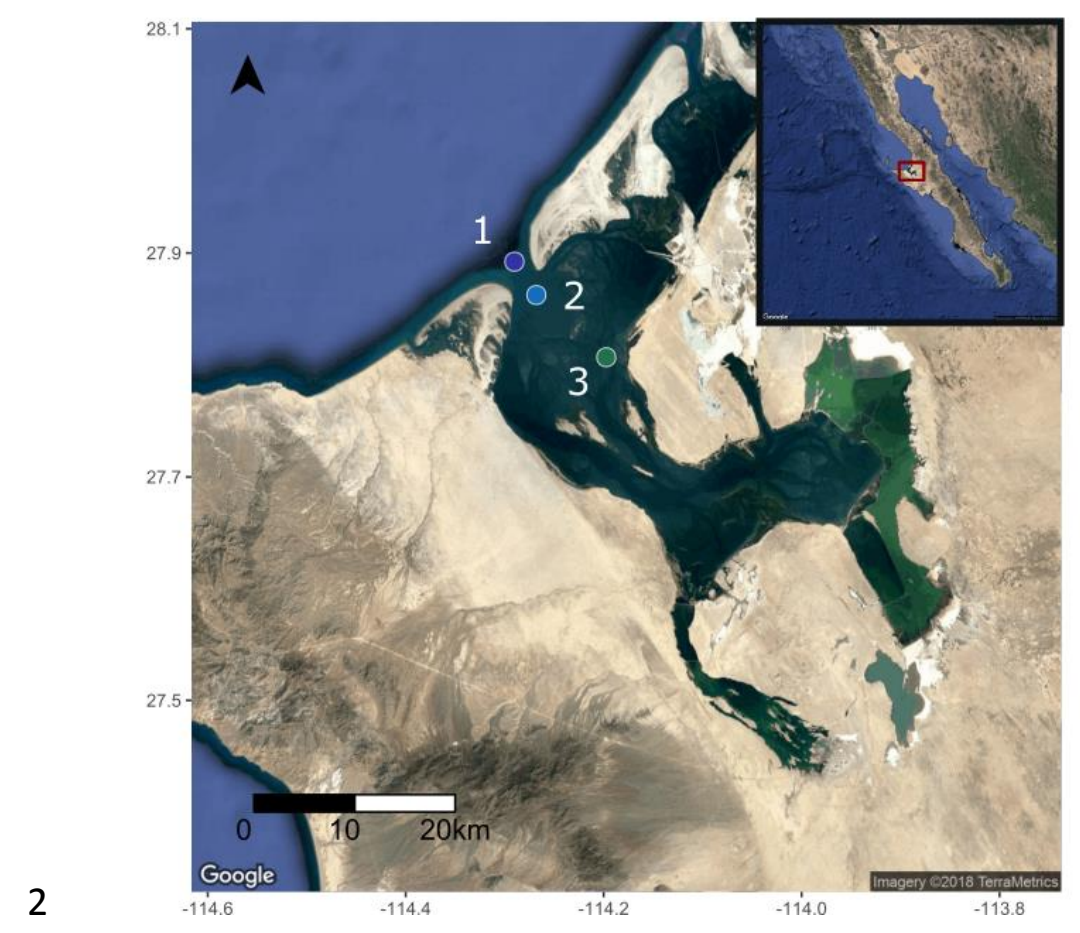

3 
Fig. 2

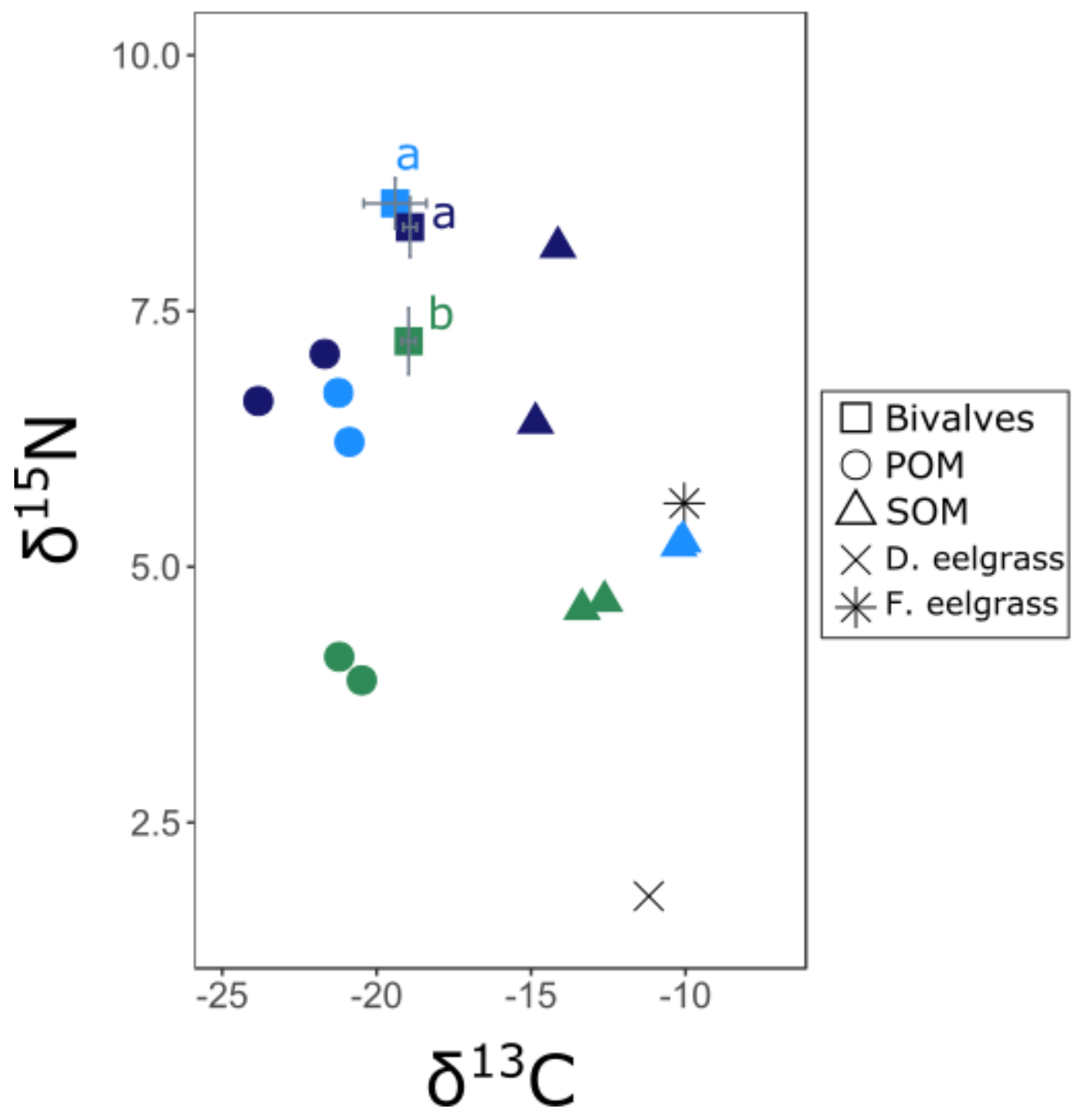

6

7 
Fig. 3

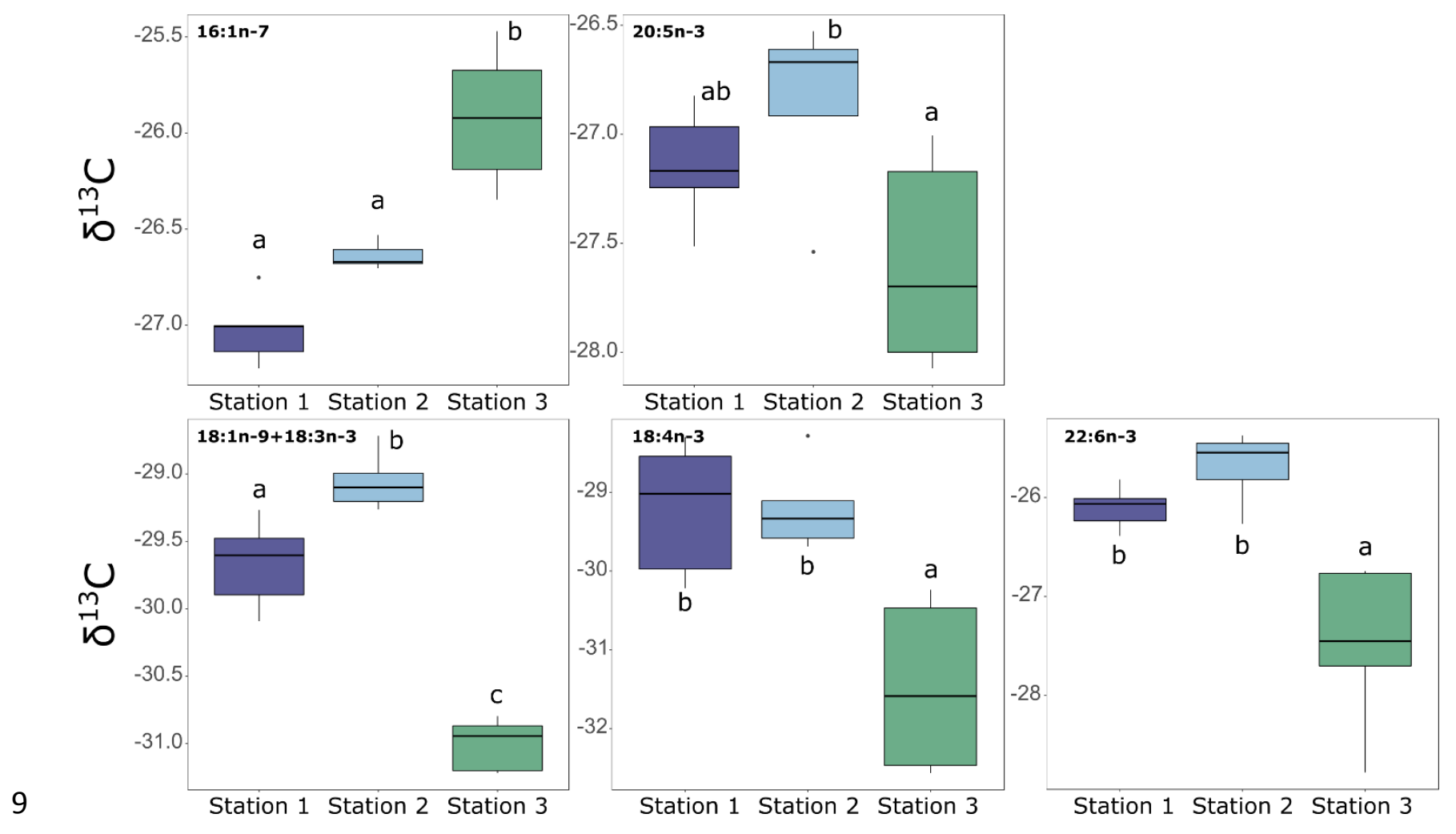

